\title{
Migration Experiences of Turkish Women: Notes from a Researcher's Diary
}

\author{
Ayșe Kadığlu*
}

\begin{abstract}
The article reviews the migration experiences of Turkish women who were either involved in external migration or were exposed to migration by being left behind upon the emigration of their husbands. It includes notes on statements made by some returning women and women whose husbands returned home.
\end{abstract}

The statements were encountered during a comprehensive field survey conducted in Turkey. Since the literature on women and external migration is, in general, blinded by a view of migrant women as "traditional" regardless of their ethnic, regional, religious and other background variables, it is expected that their exposure to the "modern" western culture will automatically pave the way to their emancipation.

The diary entries of statements made by migrant women portrayed in this article question such an axiomatic proposition by pointing to the significance of background variables and certain features of household structures.

\section{INTRODUCTION}

Labour emigration from Turkey to the industrially developed countries of North and Western Europe was unleashed in the early 1960s. The flows were mostly regulated by the Turkish and host society governments through bilateral agreements with the governments of the Federal Republic of Germany

\footnotetext{
* Department of Political Science and Public Administration, Bilkent University, Bilkent, Ankara, Turkey.
} 
in 1961, Austria, the Netherlands and Belgium in 1964, France in 1967, and Australia in 1968. The number of Turkish workers who emigrated to the Federal Republic of Germany was visibly higher than the numbers to other countries. Abadan-Unat (1975: 11) maintains that between 1961 and 1966 168,891 of the 195,095 workers who were sent abroad through official channels (i.e. about 87 per cent) went to the Federal Republic of Germany. Paine (1974: 58) calculated 85 per cent in 1967 and 80 per cent in 1972. Kubat (1979: 248) argues that of the 800,000 workers from Turkey to North Western Europe by the end of 1975, about 80 per cent went to the Federal Republic of Germany. The immigration policies of the Federal Republic of Germany over the years have clearly been more significant on the overall emigration process from Turkey than the policies of other labour-receiving countries. Because the majority of Turkish workers involved in the labour migration process in the 1960 s and early 1970s went to Germany, they were locally referred as Alamanci, i.e. Germaners, regardless of where they emigrated.

The terms of the 1961 recruitment treaty between Turkey and the Federal Republic of Germany were revised in November 1973 when the Federal government unilaterally imposed restrictions on further recruitment of guestworkers as a response to unemployment problems which were expected to worsen as a result of the energy crisis.

In the Turkish context, planners of the 1960s went so far as to include potential labour remittances in balance of payments projections. Whereas in 1964 workers' remittances represented 14 per cent of foreign currency earned in Turkey, by the beginning of the 1970s the figure had increased to 70 per cent (Kubat, 1979: 253). So dependent had Turkey's economy become on workers' remittances by the mid-1970s that the federal German government's imposition of an immigration ban in 1973 had serious consequences for the economy.

Mehrlander (1979: 147-148) notes that during the 1960s and early 1970s the majority of recruited workers were single men. After 1973, more Turkish women participated in the emigration process as a result of family reunification policies. While the immigration of single Turkish men had been restricted, emigration continued with the arrival of women and children as "dependants" - joining their husbands and fathers. Such a legal definition of women migrants as "dependants" had a major impact on their positions in the labour markets of host societies. Between 1961 and 1967, the proportion of Turkish emigrant women in the total flow of Turkish emigrants was only 15.6 per cent (Abadan-Unat, 1976: 12a). By the end of 1986, 32.2 per cent of all foreigners in the Federal Republic of Germany were females over 16 years of age, and 22.7 per cent were children under 16 years of age (SOPEMIOECD, 1988: 35). 


\section{MIGRANT WOMEN AS AN ANALYTICAL CATEGORY}

Because the problems that confront migrant women in their daily lives are quite different to those that confront women who are natives of the host society, it is appropriate to delineate ethnically or racially constructed gender roles. Many studies identify a peculiar type of discrimination involving foreign or black women. Racial discrimination is more relevant, for instance, in the United Kingdom because the majority of the migrants are British subjects from former colonies who can be distinguished by their peculiar racial traits. Turks in the Federal Republic of Germany, on the other hand, have become subjects of ethnic and legal discrimination by virtue of their visibility as a separate ethnic group and their status as foreigners.

In delineating migrant women as an analytical category, the following analysis points to the implications of their legally defined "dependent" status and the sectors to which they are confined in the labour market as well as their wages. The following analysis also depicts a recurring theme in the literature based on gross stereotypification of these women as "traditional". Simon and Brettell (1986: 11) argue that migrant women not only face discrimination within the family and the labour market of host societies due to the prevalence of a patriarchal ideology, but also because of their membership in a marginal ethnic or racial group.

Goodman (1987) observes that after arriving in the host society as dependants, migrant women usually work illegally until they obtain work permits at the end of a waiting period. Research conducted with migrant women indicates that they generally enter the lowest levels in the labour force hierarchy as domestic cleaners in private households or public buildings, waiting on tables in restaurants, or operating sewing machines. Abadan-Unat (1982: 211) notes that of 81 per cent of Turkish women engaged in production jobs in Europe, 26 per cent were employed in the metals branch, 19 per cent in textiles, 9 per cent in the food industry and 9 per cent in the chemical industry. The remainder were in the service sector, with 11 per cent in cleaning jobs. Availability of cheap female labour unprotected by labour legislation seems to keep certain secondary sectors alive in the capitalist metropoles. Morokvasic (1984: 890) points to the survival and revival of the nineteenth century sweatshop system in cities such as New York, Paris and London where women work 14 to 16 hours a day, six or seven days a week, to "catch up" for the time they are laid off without pay. The employment of female labour by immigrant entrepreneurs who depend on cheap labour and/or free labour of relatives for survival has also been documented (Anthias, 1983). Migrant women are not only disproportionately represented in the manual sectors of women's work, but also receive lower wages due to their status as "dependants". In accordance with being "dependants", their wages are viewed as "complementary", that is, part of a 
family wage; their primary occupation is to be housewives and mothers. This patriarchal ideology has an impact on the labour market position of all women regardless of whether or not they are migrants. Yet, as Morokvasic (1984: 888) argues, for migrant women it acquires a politico-legal dimension and seems more easily justifiable.

The reasons why migrant women are employed in certain jobs is usually attributed to some inferior (ironically sometimes called exotic) cultural baggage that they carry, referred to as "tradition", which seems to be characteristic of all sending societies regardless of ethnic and geographic differences. Development researchers and funding agencies are also blinded with a view that Third World women who are involved in subsistence work do not really "work", thus perpetuating the widespread notion that in these sending societies, due to cultural and religious factors, women do not work. As Morokvasic (1984: 889) puts it; no matter how insecure and poorly paid are migrant women's jobs in the host societies, they appear as nothing but a "blessing of the modern societies to the Third World women" and "as a means out of their oppressive traditions". The patriarchal nature of immigration legislation is simply a manifestation of such stereotypical generalizations about migrant women. ${ }^{1}$

The backgrounds of migrant women are very relevant in understanding their position in host societies. Engelbrektsson's (1978) studies of the impact of various background experiences of migrants from different communities in the same country point to significant differences in lifestyles in the host society that emanate from the degree of intensity of local power relationships. However, if background experiences, ethnicity, religion, culture and most importantly, tradition become the key, and in some cases the only variable in understanding the position of migrants in host societies, then the analyses cover up for the racism embedded within a patriarchal ideology perpetuated by employers and government officials. Hence, the victims are blamed for their own inferior position in the labour market. Morokvasic (1984: 889) argues that migrant women "were often labelled as victims of their tradition, of Islam, or of malechauvinist attitudes of their husbands who do not allow them to go to work".

\section{MIGRATION AND EMANCIPATION}

The prevalent theme of existing literature on migrant women revolves around the impact of labour migration on the emancipation of women (Abadan-Unat, 1977; Kosack, 1976). The most deficient aspect of this extensively studied issue is widespread utilization of the analytical categories "traditional" and "modern". As the post-war labour migration phenomenon that included women involved a movement from the industrially less developed countries of Southern Europe, North Africa and Asia to the industrially developed countries of 
North and Western Europe, most analyses were blinded with a colonial perspective that refers to the transfer of "traditional" migrants to "modern" societies. In most cases, migrants are viewed as "traditional" regardless of their geographical, ethnic, cultural, and religious differences. Moreover, emancipation, in most cases, is conceptualized by referring to the analytical category of "modern". Abadan-Unat (1977: 35) maintains that "Emancipation of any kind is closely related to the process of modernization." Hence, all the indicators of modernization identified by earlier studies - westernization, adoption of western attitudes, customs, urbanization, access to wage labour - are automatically related to the emancipation of women. The major deficiencies of such analyses stem from their tendency to neglect the backgrounds of these women. This deficiency is caused mainly by utilization of the analytical category "traditional" in identifying all background characteristics.

A study undertaken by the Organization of American Historians (1988) towards restoring women to history points to inadequacies of the concepts traditional and modern in understanding women. Indeed, these concepts have been used in the literature in a variety of contexts, and often for contradictory purposes. The editors maintain:

Since colonialist ideology in Africa, Asia, and the Middle East often used indigenous "oppression" of women as justification for intervention in these societies, they promoted the belief that the arrival of western civilization would improve women's lives (page 6).

Yet, according to the same study, the concept tradition has also been used as a rallying point in anti-colonial/liberation struggles:

In response to French cultural imperialism, wearing the veil became a political act of resistance in Algeria...Similarly, veiling became identified with opposition to western influence and to the Shah in Iran...In the 1970s President Mobutu Ses Seko of Zaire constructed his policy of authenticite, a major tenet of which was to return to the "traditional" value of women as mothers and housekeepers who obeyed male relatives (page 7).

There is no doubt that women have often been at the losing end of a return to tradition. Throughout history, both colonialism and anti-colonialism have fostered misuses of tradition. ${ }^{2}$ Hence, any interpretation of women should avoid the image of women as exotic, as victims, and as anomalies due to a tradition/modern dichotomy.

Since migrant families' primary goal is to accumulate savings, migrant women's roles have generally been directed towards increased participation in the labour markets of host societies. Many analyses in the literature therefore assign primary importance to their work experience and resulting financial independence in generating emancipation or "pseudo-emancipa- 
tion". ${ }^{3}$ Such analyses have been challenged by field surveys that question the validity of the direct correlation between their employment (in the public realm) and emancipation. One such study (Brouwer and Priester, 1983) in a village in Turkey pointed out that the increased control of husbands over wives reduced the latter's freedom of movement in the host society setting and concluded that:

....access to a wage does not necessarily imply control over the spending of that wage. The majority of Arpa (the village) women give their money to their husbands without apparent conflict... (page 127).

This observation seriously challenges previous arguments concerning the relationship between participation in the production process and emancipation. Almost all the cases reviewed in this article reveal that it is not meaningful to refer to the emancipation of migrant women, considering the labour sectors of the host societies in which they are overrepresented, their wages, acquisition of skills, illnesses related to work conditions as well as the double burden (housework and jobs), the pains associated with being removed from their children, and increased restraints on their mobility in the migration setting. Other studies have questioned the role of urbanization in migrant women's emancipation. The direct correlation between urbanization and modernization (hence, emancipation) accepted by most social scientists as an axiomatic proposition, has been challenged by others who argue that in some countries further urbanization may be negatively related to modernization. Ibrahim (1975) argues that urban centres have increasingly become the homes of millions of urban villagers who live in, but are not of, the city and find their freedom of movement increasingly restrained by their male relatives and/or husbands.

A review of the literature on modernization and changing gender roles points to a lack of shared analytical categories. Three conceptual points underline this diagnosis:

The first stems from the utilization of the analytical category "tradition". It is obvious that an overgeneralized application of this category to the backgrounds of all migrant women simply justifies an institutional sexism practised by host society governments. As an ideal-typical, polar model, this category is devoid of any analytical significance. This does not suggest a total elimination of the study of backgrounds. On the contrary, background factors, i.e. the totality of factors that give shape to the pre-migration situation of women, are in dire need of being assessed above and beyond this reductionist category. Engelbrektsson's (1978) study suggests that there are significant differences between changing gender roles of women who are from two different communities within the same country. The differences between the case of Gülizar and the cases of Sebahat and Gülseren presented below emphasize this point. 
Important differences that may account for the identification of factors shaping gender roles could very easily be disregarded by characterizing both communities as traditional.

Second, analyses regarding migrant women usually resort either to economic factors in identifying gender roles (such as urbanization, wage work) to the exclusion of other factors, or simply to cultural, ethnic and religious factors in accounting for their position in host societies. Both trends seem to overlook the importance of an overarching patriarchal ideology in shaping migrant women's work and wages. An analysis of gender roles can hardly be in touch with reality without an assessment of the implications of a prevalent patriarchal ideology. Indeed, it seems that certain low-wage jobs are increasingly being reserved for Third World women.

Third, the opposing conclusions arrived at by various studies concerning the relationship between migration and emancipation stem from radically different conceptualizations of "emancipation". Abadan-Unat (1977), for instance, points out that the possibility of engaging in conspicuous consumption as a result of earning wage income in the migration setting is a sign of emancipation. Others (e.g., Morokvasic, 1981) point to the double burden placed on migrant women who enter the wage market as they continue to be primarily responsible for fundamental household chores. International labour migration, in most cases, leads to the emergence of nuclear family organizations. For the migrants, this means the end of child-care support and help that was provided by relatives in the home society. The difficulties women face in getting professional childcare due to their migrant situation and low-wage jobs have been covered by Parmar (1984: 248). Migrant women who work outside continue to perform their private roles as housewives and mothers. In a study conducted in Canada, $\mathrm{Ng}$ and Ramirez (1980: 49) conclude:

Thus, we can speak more confidently of the "nuclearization" of domestic labour than of a full-scale change in male-female relationships in this area. This, as much as new types of market labour contribute to the "intensification" of immigrant women's work.

In some cases, migrant women leave their children in the home society to be cared for by extended kin because they cannot afford to get professional childcare in the host societies. This paves the way to fragmented families. The cases of Bagdat and Benlihan described below display very clearly the misgivings of women who pay the price of migration by being alienated from their children.

None of the factors associated with modernization prevent the perpetuation of public and private gender role dichotomies. In fact, it is possible to argue that neither secularization nor the acquisition of political rights such as voting 
addresses this dichotomy. Recognition of this dichotomy led Kandiyoti (1987) to refer to the "emancipated but unliberated" position of women in Turkey in the aftermath of the Kemalist reforms. First, working within the public realm and earning income does not necessarily lead to the emancipation of migrant women. Second, women's status within the family and marital relationships seem to vary independently of their public status in the larger society. A feminist conceptualization of emancipation must take these considerations into account. The road to emancipation lies in the extinction of this dichotomy between the public and private roles of women.

\section{MIGRATION EXPERIENCES OF TURKISH WOMEN: WASTED LIVES ${ }^{4}$}

Women are influenced by the migration experience in various ways. While some actively participate in the migration process as workers in the labour markets of host societies, others emigrate as legally defined "dependants" of their husbands or fathers and confine their activities within the household. Others are influenced by the migration experiences of their husbands even though they do not emigrate themselves. The significant differences among these various migration experiences point to the multi-faceted dimensions of the post-war labour migration phenomenon. In the following pages, the author reports some of her personal observations in the field. The real life experiences of the women portrayed are taken from the author's diary kept in the course of field research. A thorough review of the research method, selection of the sample and research sites, as well as some of the findings, were elaborated in an earlier article (Kadioglu, 1994). The cases reviewed below are based on the author's personal observations and more intimate and in-depth conversations held with respondents after the questionnaires used in the research had been completed. They are therefore less structured than questionnaire responses and may reveal variables that were not originally included or covered adequately in the questionnaires.

First, research by the author on external migration and women originated from a conviction that the subject had been inadequately covered. Previous research had evolved mainly around the relationship between emigration and emancipation, and was therefore limited by the categories traditional and modern. The present research focused on the impact of external migration on gender roles. Thus, instead of studying whether or not migrant women were finally emancipated, the author tried to unravel whether external migration had led to an assessment of change of gender roles. Structural and psychological variables were therefore taken into account and included within the questionnaires (Kadioglu, 1994: 546-547). Structural variables included women's access to social security benefits and bank accounts, their ability to visit family and friends without being chaperoned as well as the influence of husbands and 
families on their voting behaviour. Psychological variables included women's self-perceptions and views on issues such as women and work, marriage, family and the discipline of children. The conceptualization of the category gender roles not only shifted the focus of research from preoccupation with emancipation based on the tradition-modern dichotomy, but also paved the way for a study of intra-family division of labour.

Second, in order to incorporate various migration experiences, the sample was selected from amongst four types of women: first, initiators or pioneer women who were the first in their family to emigrate; second, followers with wage work experience abroad who joined their husbands or emigrated with them and had access to wage work in host societies; third, followers without wage work experience abroad whose activities remained mainly within the household; fourth, women who were left behind upon the emigration of their husbands (Kadioglu, 1994: 539). In addition to these groups, a non-migrant control group, selected proportionately from similar research sites was included to serve as a basis of comparison. All the women were located in the return context. Hence, their migration experiences were assessed ex post facto, i.e. after their own or their husbands' return home.

Third, the surveys were conducted in three different sites classified according to levels of industrial development, economic diversification, and urbanization (Kadioglu, 1994: 540). These included an industrial metropolis (Ankara); a provincial, industrializing town inhabited by returnees of different ethnic and religious origins (Kirșehir); and various villages in the vicinity of this town (Kortulu, Karakurt, Karacaören, Toklümen, Siddikli, Cepni, Barakli, and Akbiyikli). Each site bore witness to mass migrations to North and Western European countries.

The research documented different experiences of these four types of women who had experienced external migration as well as their differences from the non-migrant control group in terms of the structural and psychological determinants of gender roles. Each of the following cases related to women who returned to Ankara.

The research suggested that whether the family of the migrant workers was extended or nuclear prior to emigration has crucial implications for the styles of exposure to migration (Kadioglu, 1994: 555/Table 2). Women who lived with their husbands' extended family prior to emigration continued to do so after their husbands had left. Hence, male and/or older female members of the household other than the wives assumed responsibilities in the absence of the migrant men. As a result, wives maintained their subservient status. In rare cases, what were initially nuclear families had evolved into extended ones due to emigration of husbands. The case of Gülizar (included in the preliminary survey) illustrates this point: 
The case of Gülizar

Gülizar's husband owns a small store selling household goods in the Erzurum neighbourhood in Ankara. He stayed in the Federal Republic of Germany for fifteen years and returned permanently a few years ago. Gülizar stayed behind with two babies at the time of her husband's emigration. She and her babies were placed under the care of her father-in-law who was specifically brought to Ankara from his village in Erzurum to attend to his son's family. Gülizar's husband had come back occasionally to visit his family. Over the years, she gave birth to another son. Throughout her husband's absence, the head of the family was Gülizar's father-in-law. Gülizar's husband said that his absence turned his wife into a "crazy woman".

Gülizar met me in their house, which was located next to her husband's store. I asked her if she could tell me how her husband's absence changed her lifestyle. She said that her biggest problem was missing her husband. Theirs was not a marriage arranged by their families; they had got married in the aftermath of a romantic relationship. She thought she was too young to be left without a husband. After living with her father's extended family in their village for a while, they moved to Ankara with her husband. Before her husband left for Germany, they had a nuclear household for two years in Ankara. Afterwards, her father-in-law - who was not very understanding - became the head of the family. Gülizar complained about the fact that he did not give her and her children enough food. He did not buy them clothes. In short, he had a monopoly over spending of the money that was sent back home by his son. Some of the financial affairs of the family were handled by her husband's brother. Therefore, her husband's absence did not present Gülizar with new responsibilities within the public realm. The absence of her husband led to the reinstitution of an extended family style for Gülizar and her children. Previously, her husband had accompanied her to the food bazaar. After his emigration, her brother-in-law began to escort her. She did not handle any of the monetary matters. Gülizar is illiterate and could not write private letters to her husband in order to inform him about her complaints and misgivings concerning her father-in-law.

Gülizar said that her husband's absence made her closer to her children. She feels sorry that they do not recognize their father very well since he was away when they were growing up. During the later years of her husband's absence, Gülizar started to have nervous problems and was taken to a doctor. She said she was happy that her husband finally came back home before she completely turned crazy. She seemed very emotional when talking about her nervous disorder.

External migration turned Gülizar's family from a nuclear into an extended one. The family stayed extended after the husband's return. Emigration did not present Gülizar with public roles outside the household. The only positive impact of her husband's emigration is the close relationship that Gülizar could establish with her children. She was clearly very well respected and loved by them. The children seemed quite distant in their relationship with their father. 
In many other cases, emigration of the husband is the reason why some families became nuclear households. This is usually the case when the husband's emigration is from a village, initially leaving behind his wife and children with the extended kin. Later, when he starts to accumulate savings, he usually buys a flat in big city and is joined by his wife and children. As part of fragmented families, they lead unchaperoned lives, i.e. they are supervised neither by their husbands nor their extended kin. Despite initial difficulties as a result of being active within the unfamiliar public domain (activities such as shopping, undertaking transactions in banks and governmental offices, utilization of remittances), women in these situations experience a drastic change in gender roles compared with dependent migrant women who accompany their husbands abroad but are confined within the household while residing there. The differences are highlighted by the experiences of Sebahat and Gülseren on the one hand, and Perihan on the other:

\section{The cases of Sebahat and Gülseren}

Sebahat and Gülseren are the wives of two brothers who went to the Federal Republic of Germany as guestworkers and stayed there for about twenty years. When Sebahat's husband left, she stayed behind in their village in Yozgat. She lived in a separate house with her two children for a while. Her house shared a common yard with the houses of the wives of her husband's brothers who also worked abroad. The left-behind wives took care of their children and helped each other in sharing responsibilities outside the household. One of these women, Gülseren, occasionally hosted their mother-in-law in her house. When Sebahat's husband came back in the early 1980s, he bought a piece of land in Dikmen, Ankara. He and a developer collaborated in the construction of an apartment complex on this land. He owns 60 per cent of the flats. His family resides in one of them today. When Sebahat's family moved to Dikmen, the other families bought flats and followed suit. Gülseren's husband returned two years ago. In the absence of their husbands, a sisterly relation developed between these left-behind women. Gülseren said that if one of them got sick, they all went to the doctor's office together in order to support each other.

Both Sebahat and Gülseren took upon themselves new responsibilities in the public realm during the absence of their husbands. The male relatives of their husbands did not perform such responsibilities (contrary to the case of Gülizar above). Rather, these women helped each other out and formed a kind of women's support group. They became a group of decision-makers. Today, their husbands have to consult them before making major decisions concerning their and their children's lives. In fact, the children in these families did not know their fathers very well and recognize their mothers as the head of the family. The fact that these women were literate facilitated their adaptation to their new environments.

\section{The case of Perihan}

Perihan's husband stayed abroad for sixteen years. Perihan was with him for 10 years. She left Turkey together with her husband immediately after they got 
married. Perihan did not work outside the household while they were abroad. She attended the house, did all the housework and cared for her children. Perihan's husband did not want her to work while they were abroad. He said: "Those people are Europeans. They are different than us and as a result they do not know our folk and tradition. They may try to become friendly or may joke around. Even though they may not mean any harm, their actions may be disrespectful for our women and may damage our honour." Therefore, he thought it was best to keep a distance from them. Perihan's husband seemed proud of the fact that his wife does not wear loose and long pants (șalvar) under her skirt after the migration experience. She wears western clothes. Still, she covers her head with a handkerchief now that they are back in Turkey since her husband does not want their neighbours to think that she had forgotten certain Turkish customs.

It was very clear that Perihan's husband was the head of the household. He decided on the limits of Perihan's activities and the style of her costumes. He viewed Perihan's appearance as a statement about his identity and honour. Not wearing the șalvar seemed critical for Perihan's husband for being modern. Perihan said that she covered her head in Turkey upon return due to the conservative ways of their neighbours. They began to live in the Erzurum neighbourhood in Ankara upon return. As she put it: "We are not from Erzurum. We are natives of Ankara. Therefore, we are different from these people." Perihan and her husband viewed themselves as more modern than their neighbours.

In some migration situations where migrant women have salaried employment outside the household, they complain about the intensification of their workload and early ageing under the double burden of wage work and household work. Moreover, in order to work outside the household, they leave their children in their home societies under the care of their kin and hence sacrifice their roles as mothers in order to perform their duties as economic partners. The cases of Bagdat and Benlihan illustrate these points:

\section{The case of Bagdat}

Bagdat's husband went to the Federal Republic of Germany in 1974. Bagdat joined him two years later. They are both from a village of Çorum, located towards the north of central Anatolia. Bagdat had completed primary school in her village. She stayed in the village in a separate household when her husband left. When he came to pick her up and take her with him to Munich, she left her baby boy with her mother-in-law. She worked at the Siemens factory for ten years. She describes her work as very heavy and dangerous. She witnessed many workplace accidents. A few years after they moved to Munich, she got pregnant. She went back to Turkey in order to give birth to her second child. She then left both of her children with her mother-in-law and went back to work in Munich. Bagdat's major misgiving about her migration experience is the emotional distance she feels between herself and her older son who grew up with his grandmother. Now that Bagdat and her husband are back together as a 
nuclear family, their older son has problems recognizing them as authority figures and constantly disobeys them. Bagdat says: "He tortures me emotionally and makes me feel guilty for leaving him behind."

Bagdat also thinks that the migration experience and the heavy work conditions in Munich caused early ageing in her case. She feels very old and tired. Her case illustrates the irrelevancy of inquiries into whether work outside of the household made women more liberated! The way she describes her work conditions and the fact that she only worked to save and now wants to forget about those difficult times, makes another dent in the long accepted thesis that wage work leads to liberation and emancipation. Bagdat thought that she would never have worked in a factory if she had stayed in her village. She also learned to speak German. She said that they would not be able to live in their house in the Dikmen neighbourhood in Ankara and send their children to school if they had not been to Munich. As she puts it: "The benefits of our migration experience are under the feet of our children. I want more than anything else in the world that they take advantage of it and become educated individuals. My life passed me by working in jobs that Germans would not, while being separated from my children. I hope it will be of use to them."

Bagdat's relationship with her husband seemed quite different to the other cases. It was less hierarchical and more companionate and romantic. She seemed very fond of him and he was quite attentive towards her. Theirs was not a marriage arranged by families but out of their love for each other. Unlike all the other cases, he consistently served his wife (as well as the female researchers) tea and cookies. He seemed quite involved in housework, including cooking. Just as the researchers were taking account of the romantic nature of the couple's relationship and the more egalitarian division of labour between them within the household, Bagdat confided to them that they are Alevites, i.e., a sect of Muslim religion which is different from the Sünni sect that the majority of Turks accept. The extraordinariness of Bagdat's relation to her husband, as well as Bagdat's playfulness and interest towards her surroundings, prompted the researchers to take account of her religious affiliations. Yet the researchers had to give up pursuing such a connection since questions regarding one's religious affiliations in Turkey are considered to be excessively inquisitive or nosy.

Mirdal (1984), who conducted a field study with Turkish female immigrants in Denmark, points out that Turkish women continue to work in hard, dirty and perilous jobs for fear of becoming unemployed, even when they experience illnesses related directly to their work conditions. Eczema, backache, and various dermatological problems related to detergents used in cleaning are reported in many cases. Moreover, complaints of a somatic nature, such as "muscular pains, ring around the chest, tightness in the chest, trembling, feeling chilly, chills running up and down the spine, a lump in the throat, pounding of the heart, cold feet" are reported to be common among the Turkish women in Mirdal's (1984: 999) sample. Benlihan's case illustrates these points: 


\section{The case of Benlihan}

Benlihan and her husband stayed in Munich for twelve years. They are both from Hacibektas, a village of Nevșehir located in central Anatolia. Benlihan's husband left for Munich in 1972. She stayed behind in Hacibektaș with her two babies. Her in-laws interfered with her life quite often. After a while she decided that she could not live in Hacibektas without her husband and accompanied him to Munich at the end of one of his visits. She left her two children with her mother-in-law. When she arrived in Germany as a "dependent" spouse, she did not have a work permit and was willing to work at any job. She obtained a cleaning job in a school. She told me that it was a huge building encompassing primary, secondary and high schools. She cleaned the entire complex on her own. She told me that the school was so big that sometimes she would lose her way and get scared. She said she used to leave her brush and other cleaning materials on her path in order to find her way back to the entrance. She did all the cleaning in the evenings. As a result, she did not see her husband very often. He was working both day and night shifts. She prepared meals for both of them in the mornings.

Benlihan could neither speak nor read German and therefore was unable to read the warning signs on the cleaning liquids. After a while, she began to develop severe allergies on her hands, arms and legs. Only after being hospitalized, she found out that she was supposed to wear gloves while doing her job. After four years, Benlihan obtained a work permit and began work in a factory assembling electrical appliances. There were many other women, (Turks, Yugoslavians, Italians and Greeks) in the same factory. She became friends with some of these women. She described in detail a day she could not forget while working there. That was the day of a New Year's Party and everybody in the workplace began to hug and kiss each other to celebrate. Benlihan was horrified as she thought some of her male managers might try to hug her too. In fact, one of them did try to give her a kiss while everybody else was staring at her. It turned out that they were doing it deliberately to tease her, as they knew she would be embarrassed. In the end, nobody kissed her and everybody laughed and had a good time. Benlihan remembers this as a very embarrassing moment. She said that she believed it should be all right to have a good time with friends but her husband did not feel the same way. She worked at this factory for six years. It was very detailed work and required a lot of attention. This job ruined her eyesight and she had to be medically treated many times after quitting.

The jobs that Benlihan held while residing in Munich did not enhance her skill level. Rather they were detrimental to her health. She worked in order to save and send it to her in-laws so that they could take care of her children. She seemed jealous of her in-laws, as they were receiving some of both her and her husband's savings and disposing of them freely. Moreover, they were getting closer to her children while Benlihan herself was becoming more alienated from them. She said: "If I had stayed behind, my in-laws would still receive my savings and interfere with my life. So, I decided to get away. Both my husband and his family did not let me take my children with me. I killed myself working in Munich and yet it did not do me any good. Moreover, it had cost me the love of my children, as they did not know me as their mother for a long time. Even 
today, under the same roof, I feel removed from them. I gave all my savings to my husband to be sent to my children."

Migration experience altered Benlihan's life in a fundamental way. She moved out of the village, experienced new people, made new friends. Yet all of these changes did not make her any happier as she constantly missed the love of her children. Her labour remained unrecognized. The only positive gains are the material things that her family acquired. Today, the family lives in their own house in Ankara. The house is fully furnished with television sets, radios, oven, washing machines. They have some savings to spend for the rest of their lives and expect to receive retirement benefits soon. They are able to send their children to the university. Other than these aspects, migration experience made Benlihan ill and unhappy.

\section{CONCLUSIONS}

Migration experiences of women are too multi-faceted to warrant a single categorization. In fact, what is usually experienced abroad, in the migration setting, is a continuation of processes that had already begun in the home society. Some of the points that can be derived from the above cases are as follows:

First, various dimensions of the background experiences of these women may account for the way they react differently to the changes they confront as a result of migration. There are a wide range of customs that determine behaviour patterns in different regions in Turkey. Hence, the regional origins of the migrants account for their different reactions to the migration experience. Moreover, factors such as type of family (nuclear or extended), marriage patterns (arranged by families or romantic), religious affiliations, and levels of education seem also to account for differences in the migration experiences of women. The case of Bagdat, for instance, portrays the significance of background variables in giving shape to the migration experience. Migrant women are not tabulae rosa preceding emigration. Bagdat, for instance, who came from an Alevite background and who married her husband out of love (rather than acquiescing to an arranged marriage) ended up experiencing more companionate relations with her husband in the return setting. Yet, it seems that her relationship with her husband was already companionate before emigration. Bagdat lived with her husband in a nuclear household before and after emigration. Gülizar and her husband also lived in a nuclear household prior to the husband's emigration. Yet, after his emigration, his extended kin moved into their household in Ankara and Gülizar's father-in-law became the head of the family. Gülizar and her husband were from a different regional background (Erzurum) than Bagdat who was from Çorum. Gülizar was illiterate whereas Bagdat had completed primary school in her village. The circumstances surrounding Gülizar's life made her quite dependent on her in-laws after her 
husband's emigration. She continued to live with her husband's family in Ankara, away from her village, after he left. Her lifestyle was controlled by them. She was at times harassed and looked down upon by her in-laws. In sum, a comparison of Bagdat's and Gülizar's cases points to the importance of background variables in giving shape to their migration experiences.

Second, when Gülizar's case is compared with the cases of Sebahat and Gülseren who were also left behind, the significance of staying within a nuclear household after the emigration of the husband becomes quite evident. Contrary to Gülizar, Sebahat and Gülseren stayed with their children in their own nuclear household freed from the supervision of their in-laws. Moreover, they formed a support group with other women with whom they shared their problems. They undoubtedly had become the heads of their households during their husbands' absence. They had become solely responsible for the dispensing of their husbands' savings for the benefit of the family as well as for raising their children. They became quite active in the public domain, shopping, undertaking transactions in banks and government offices. They also acted as single parents in the absence of their husbands and earned the love and respect of their children. Still, both Sebahat and Gülseren complained about having to live in fragmented family structures.

Third, a comparison of Sebahat's and Gülseren's experiences with Perihan questions the overgeneralized myth regarding the positive impact of emigration on women from "traditional" societies. Perihan, who joined her husband in the migration setting, did not work while abroad. Her husband was (and still is) over-protective towards her and did not want her to intermingle with the "corrupt" western culture. Hence, although she emigrated and lived in a western society, she was not exposed much to the western culture. She thought she had been adequately westernized by virtue of wearing western clothes in spite of the fact that she continued to cover her head. Her westernization stayed at the level of costumes. ${ }^{5}$ Compared with Perihan, Sebahat and Gülseren never emigrated but experienced a major change in terms of their gender roles upon their husbands' emigration in spite of the fact that their costumes and outlook remained more traditional than Perihan. A comparison of the cases of these three women questions the axiomatic proposition that migration and exposure to western culture ipso facto paves the way to the emancipation of women. Perihan's case illustrates how migrant women who do not experience wage work abroad are confined in small apartments and live quite lonely lives. They miss some of the freedom of movement in their villages, a theme depicted by the Turkish writer Akçam, (1973: 199) in which he expresses a migrant woman's longing to return to her village:

A rock is heavy only where it stands...A wind blew and dragged me here...I was a lion on my own mountain; now I'm being fed to foxes and jackals. I used to be a nightingale in my own gardens; now crows and magpies peck away at me. I 
lost my tray, my table, my food, my bread. I lost my circle of friends...I am a daughter of snow-capped mountains, of flowers and meadows, of plains and fields that smell lovely...This is not the city I came to. With my own feet, I walked straight into a graveyard. ${ }^{6}$

The women left behind in nuclear households upon the emigration of their husbands experienced more significant changes in terms of their gender roles when compared with migrant women who did not work in the migration setting and whose activities were controlled by their husbands.

Fourth, some of the migrant women left their children behind with their extended families in the home society. In the cases of Bagdat and Benlihan they suffered from the alienation of their children and regretted that they were unable to bond with them over the years. Although they benefited financially from the migration experience, and secured a comfortable life for themselves upon return, it had cost them a closer relationship with their own children. They seemed quite unhappy about missing or rather delaying for a long time their chance to enjoy being parents in life.

In the light of the cases reported in this article, it is possible to argue that migration experiences provided women with some financial security. Returning migrants live in flats that they usually own. If they return back to their villages, they have new houses built that stand out with their style of architecture, colours, furniture and appliances. Nevertheless, it is obvious that the lives of these women passed them by either waiting for their husbands to return, or working in perilous jobs abroad trying to save their incomes while being alienated from their children. In some cases, migrant women experienced illnesses and psychological disorders related either to their work conditions or because of being separated from their families for prolonged periods of time. Despite differences regarding migration experiences, almost all the women suffered under the double burden of having to perform public and private roles. The post-war European labour migration did not lead to an alteration of private gender roles and the division of labour within the household, even though in some cases it paved the way for acquisition by women of certain roles in the public domain. 


\section{NOTES}

1. Institutionalized racism in Britain in 1978 led to the humiliation and abuse of Asian migrant women when they were subjected to vaginal examinations by immigration officials before they were granted permission to enter the country as dependent spouses. These examinations were based on the assumption that Asian women, due to their cultural and religious backgrounds, are always virgins before they get married. Thus virginity was viewed as proof of unmarried status and would bar entry as spouses (Parmar, 1984: 245).

2. See, for instance, the paradoxical arguments of the colonial feminists in late nineteenth century England who became champions of the unveiling of women in Egypt (Ahmed, 1992: 151).

3. The notion "pseudo-emancipation" is employed by Abadan-Unat to denote a kind of financial autonomy acquired in the public realm due to emigration signified in the adoption of consumption oriented behaviour patterns (Abadan-Unat, 1977). Kosack (1976), for instance, assumes that active involvement in the production process, having the same power as all productive workers and getting involved in their struggles, are preconditions for migrant women's emancipation.

4. In this section, the author will refer to her own experience in the field while she was involved in research titled "Impact of Migration Experiences on Gender Roles" conducted in Turkey. While the preliminary survey was undertaken in 1989, extended research lasted from 1990 to 1992. This research was made possible by a generous grant offered jointly through the Middle East Awards Programme (MEAwards) and the Middle East Research Competition (MERC), sponsored and funded by the Ford Foundation and the Population Council. The author acknowledges their support.

5. I had earlier referred to the Kemalist Turkish women who also emphasized costumes as emblems of modernity as modernes de robe (modernity by virtue of clothes) (Kadioglu, 1994a: 653). Perihan, whose life was controlled by her husband, thought that she was westernized by virtue of her clothes and looked down upon her neighbours who continued to wear traditional, rural Turkish costumes.

6. Cited in and translated into English by Halman, 1985.

\section{REFERENCES}

Abadan-Unat, N.

1977 "Implications of migration on emancipation and pseudo-emancipation of Turkish women", International Migration Review, 11(1): 31-57.

1982 "The effect of international labor migration on women's roles: the Turkish case", in Çigdem Kagitçibași (Ed.), Sex Roles, Family and Community in Turkey, Indiana University Press, Bloomington.

Abadan-Unat, N., et al. (Eds)

1975 Migration and Development: A Study of the Effects of International Labor Migration on Bogazliyan District, Ajans-Türk Press, Ankara. 
Abadan-Unat, N., et al. (Eds)

1976 Turkish Workers in Europe, 1960-1975: A Socio-economic Reappraisal, E. J. Brill, Leiden.

Ahmed, L.

1992 Women and Gender in Islam: Historical Roots of a Modern Debate, Yale University Press, New Haven, London.

Akçam, D.

1973 "Köyden Indim Șehire”, Türk Dili, 261, June.

Anthias, F.

1983 "Sexual division and ethnic adaptation: the case of Greek-Cypriot women" in Annie Phizacklea (Ed.), One Way Ticket: Migration and Female Labor, Routledge and Kegan Paul, London.

Brouwer, L., and M. Priester

1983 "Living in between: Turkish women in their homeland and in the Netherlands", in Annie Phizacklea (Ed.), One Way Ticket: Migration and Female Labor, Routledge and Kegan Paul, London.

Engelbrektsson, U.-B.

1978 The Force of Tradition: Turkish Migrants at Home and Abroad, Gothenburg Studies in Social Anthropology, Gothenburg.

Goodman, C.

1987 "Immigration and class mobility: the case of family reunification wives in West Germany", Women's Studies, 13(3): 235-248.

Halman, T. Sait

1985 "Big town blues: peasants abroad in Turkish literature", in Ilhan Başgöz and Norman Furniss (Eds), Turkish Workers in Europe: An Interdisciplinary Study, Indiana University Turkish Studies 5, Bloomington.

Ibrahim Saad Eddin

1975 "Overurbanization and underurbanism: the case of the Arab world", International Journal of Middle East Studies, 6: 29-45.

Kadioglu, A.

1994 "The impact of migration on gender roles: findings of field research in Turkey”, International Migration, 32(4): 533-561.

1994a "Women's subordination in Turkey: is Islam really the villain?", Middle East Journal, 48(4): 645-660.

Kandiyoti, D.

1987 "Emancipated but unliberated? Reflections on the Turkish case", Feminist Studies, 13(2): 317-338.

Kosack, G.

1976 "Migrant women: the move to Western Europe - a step towards emancipation", Race and Class, 17(4): 369-379.

Kubat, D., et al. (Eds)

1979 The Politics of Migration Policies: The First World in the 1970s, Center for Migration Studies, New York.

Mehrlander, U.

1979 "Federal Republic of Germany" in D. Kubat et al. (Eds), The Politics of Migration Policies: The First World in the 1970s, Center for Migration Studies, New York. 
Mirdal, G.M.

1984 "Stress and distress in migration: problems and resources of Turkish women in Denmark", International Migration Review, 18(4): 984-1003.

Morokvasic, $\mathrm{M}$.

1981 "The invisible ones: a double role of women in the current European migrations", in L. Etinger and D. Schwarz (Eds), Strangers in the World, Hans Huber Publishers, Bern.

1984 "Birds of passage are also women", International Migration Review, 18(4): 886-909.

$\mathrm{Ng}, \mathrm{R}$., and J. Ramirez

1980 Immigrant Housewives in Canada, Immigrant Women's Center, Toronto. Organization of American Historians

1988 Restoring Women to History, Bloomington, Indiana.

Paine, $\mathrm{S}$.

1974 Exporting Workers: The Turkish Case, Cambridge University Press.

Parmar, P.

1984 "Gender, race and class: Asian women in resistance", The Empire Strikes Back: Race and Racism in 70s Britain, Centre for Contemporary Cultural Studies, University of Birmingham.

Simon, R.J., and C. Brettell (Eds)

1986 International Migration: The Female Experience, Rowman and Allanheld Publishers, New Jersey.

SOPEMI-OECD

1988 Continuous Reporting System on Migration, 1987, Organisation for Economic Co-operation and Development, Paris. 


\section{L'EMIGRATION TELLE QUE VECUE PAR LES FEMMES TURQUES : NOTES DU JOURNAL D'UN CHERCHEUR}

Cet article décrit le vécu de l'émigration par les femmes turques ayant ellesmêmes émigré ou ayant vécu l'expérience de rester seules au pays après le départ de leur conjoint pour l'étranger. Il contient des notes relatives aux impressions recueillies auprès des intéressées dans ces deux types de situation.

Les propos des personnes interrogées ont été notés à l'occasion d'une vaste enquête menée en Turquie. Comme la littérature concernant les femmes et l'émigration est généralement biaisée par une perception "traditionnelle" des femmes migrantes, indépendamment de leur origines ethniques et géographiques, de leur confession et d'autres facteurs, on s'attend que leur exposition à la culture occidentale "moderne" les conduise automatiquement dans la voie de l'émancipation.

Les impressions recueillies par l'auteur dans son journal mettent en doute cet axiome en faisant ressortir le poids des caractéristiques originelles et certaines autres considérations liées à la structure du ménage.

\section{EXPERIENCIAS MIGRATORIAS DE MUJERES TURCAS: NOTAS DEL DIARIO DE UN INVESTIGADOR}

El artículo examina las experiencias migratorias de las mujeres turcas que participaron en migraciones externas o que se vieron expuestas a la migración al quedarse tras la emigración de sus cónyuges. Incluye notas sobre declaraciones formuladas por algunas mujeres retornantes y mujeres cuyos maridos retornaron al hogar.

Estas declaraciones forman parte de una extensa encuesta en el terreno realizada en Turquía. Habida cuenta de que, por lo general, la documentación existente sobre mujeres y migración externa está cegada por la visión de la mujer migrante como "tradicional" a pesar de sus antecedentes étnicos, regionales, religiosos y otros, y deja suponer que su exposición a la cultura occidental "moderna" conducirá automáticamente a su emancipación.

Las inscripciones en el diario de las declaraciones formuladas por mujeres migrantes descritas en este artículo cuestiona esta hipótesis al señalar la importancia de las variables en los antecedentes y de algunas características en las estructuras familiares. 